\title{
Szemléletváltozás a Down-szindrómás szívbetegek szívsebészeti kezelésében, 1974-2016
}

\author{
Hartyánszky István dr. - Bogáts Gábor dr. \\ Szegedi Tudományegyetem, Általános Orvostudományi Kar, Szent-Györgyi Albert Klinikai Központ, \\ II. Belgyógyászati Klinika, Szívsebészeti Osztály, Szeged
}

\begin{abstract}
Bevezetés: Down-szindrómás betegeknél gyakori a veleszületett szívfejlődési rendellenesség. Célkitüzés: A szerzők megvizsgálták, hogy a szívsebészetben bekövetkező szemléletváltozások hogyan befolyásolják a Down-szindrómás szívbetegek életkilátásait. Módszer: 1974-1997 között a szerzók 359 Down-szindrómás szívbeteg gyermek adatait elemezték. 255 esetben nem történt beavatkozás, a mortalitás $25,9 \%$ volt, 104 esetben végeztek mútétet 8,6\%-os mortalitással. Eredmények: Az összehasonlító vizsgálatok igazolták, hogy a sikeres mútéti beavatkozás ugyanazt az életkilátást biztosítja a Down-szindrómás betegek számára, mint nem szívbeteg társaikénak. Azóta jó eredményekkel történnek csecsemőkori primer rekonstrukciós beavatkozások. Napjainkra már fokozatosan növekszik a felnőttkort megélő operált és nem operált veleszületett szívbetegek száma. A legutóbbi három év alatt 82 felnőtt, közöttük 4 Down-szindrómás betegen (életkoruk 24-60 év) végeztek sikeres szívsebészeti korrekciós mútétet. Következtetések: A csecsemőkori szívsebészeti beavatkozások eredményeként fokozatosan nő a felnôttkorú veleszületett szívbetegek száma. A szívsebészek készek javítani e betegek optimális életkilátásait, azonban a Down-szindrómás betegeknél jelentkező speciális problémák (reoperációk indikációja, szükségessége, életkor megválasztása stb.) még nem megoldottak, és kihívást jelentenek a kardiológusok, szívsebészek számára. Orv. Hetil., 2016, 157(40), 1601-1603.
\end{abstract}

Kulcsszavak: Down-szindróma, felnőttkori congenitalis szívbetegek, sebészi kezelés

\section{Change in our approach in the surgical management of congenital heart defects in patients with Down syndrome, 1974-2016}

Introduction: Congenital heart defects are frequently present in patients with Down syndrome. Aim: The authors analyzed the impact of changing approach in surgical management of congenital heart defect on the life expectancy of patients with Down syndrome. Method: Between 1974 and 1997 the data of 359 children with Down syndrome were collected. Among them 255 patients had no surgery and the mortality in this group was $25.9 \%$, whereas the mortality in the group of 104 patients who underwent palliative surgery was $8.6 \%$. Results: Surgical management of congenital heart defects provides the same life expectancy for these patients as compared to Down patients without cardiac defects. Primary reconstruction is the preferable surgical procedure in infancy that provides good results. Nowadays the number of the operated grown-up congenital heart disease patients with Down syndrome is increasing. During the last three years 82 grown-up congenital heart disease patients, including 4 patients with Down syndrome (aged between 24 and 60 years) were reconstructed successfully. Conclusions: Due to the successful surgery in infancy the population of grown-up congenital heart disease patients with Down syndrome is increasing. The cardiac surgeons are ready to do everything for the optimal life expectancy of these patients. However, management of special problems (indication and necessity of reoperation, optimal age) in patients with Down syndrome poses a great challenge for cardiologists and cardiac surgeons.

Keywords: Down syndrome, GUCH, cardiac surgical management

Hartyánszky, I., Bogáts, G. [Change in our approach in the surgical management of congenital heart defects in patients with Down syndrome, 1974-2016]. Orv. Hetil., 2016, 157(40), 1601-1603.

(Beérkezett: 2016. május 26.; elfogadva: 2016. augusztus 3.) 
Az élve született újszülöttek 0,19\%-a Down-szindrómás. A Down-szindrómás újszülöttek 40-60\%-ánál veleszületett szívfejlődési rendellenesség áll fenn, amelyeknek 90-95\%-a bal-jobb sönttel járó szívhiba, dominálóan atrioventricularis septumdefektus. Ezeket a szívhibákat a pulmonalis hypertonia megelőzése miatt már csecsemőkorban operálni szükséges. Az 1990-es éveket megelőzően csak palliatív beavatkozás, az arteria pulmonalis törzs beszúkítése jelentette a megoldást, majd kisded-, gyermekkorban tervezetten kerülhetett sor a rekonstrukcióra. Azokban az esetekben, amikor a jobb atrioventricularis billentyü is insufficiens volt, e beavatkozás nem járhatott eredménnyel (az arteria pulmonalis törzs szúkítése növelte a tricuspidalis billentyű elégtelenségét), ezért ezeket a betegeket inoperábilisnak kellett nyilvánítani. Az 1990-es évekre teremtődtek meg a feltételek arra (anesztézia, szívmotor, perfúziós technika, posztoperatív kezelés, NO-alkalmazás stb.), hogy újszülötteken a szívmotor védelmében biztonságosan lehessen korrekciós szívműtéteket végezni. Így az eddig inoperábilisnak tartott atrioventricularis septumdefektusos újszülötteknél és csecsemőknél is korrekcióra kerülhetett sor. Ezek közé tartoztak a Down-szindrómás betegek is. Ekkor vetődött fel a kérdés, hogy szabad-e, érdemes-e ezeket a betegeket mütéti megterhelésnek kitenni, a sikeres mütét javítja-e az életminőségüket, meghosszabbítja-e az életüket, vagy az élettartamuk az Edwards- és Patau-szindrómás betegekéhez hasonlóan behatárolt.

\section{Módszer}

A hazai viszonyokat tisztázandó országos felmérést végeztünk, választ várva azokra a kérdésekre, hogy 1. Operáljuk-e a Down-szindrómás szívbetegeket? Kinek a felelőssége dönteni a mütétről: szívsebésznek, gyermekkardiológusnak vagy gyermekgyógyásznak? 2. Milyenek a Down-szindrómás szívbeteg gyermekek életkilátásai mútét nélkül, palliáció, palliáció + rekonstrukció, primer korrekció után? 3. Hasonlóságot kerestünk sikeres szívmütéten átesett és nem szívbeteg Down-szindrómás gyermekek sorsa között. 4. Összehasonlítottuk az azonos típusú mütét eredményeit Down-szindrómás és nem Down-szindrómás gyermekeknél.

\section{Eredmények}

Az 1974 és 1997 között 30 gyermekkardiológiai gondozónál nyilvántartott 359 Down-szindrómás szívbeteg gyermek adatait elemeztük. 359 beteg közül 75 (20,9\%) hunyt el; a 255 nem mütött betegből 66 beteg $(25,9 \%)$, míg a 104 operált beteg közül 9 beteg $(8,6 \%)$ halt meg.

Vizsgálataink során a következőket állapítottuk meg: 1. A palliatív vagy kétlépcsős korrekciós műtét javít a Down-szindrómás szívbetegek életkilátásain, de a legmegfelelőbb megoldás a korai primer rekonstrukció. Mütét nélkül az egyszerü vitiumban szenvedők 10\%-a, a komplex vitiumos betegek 40\%-a még csecsemókorban meghal. 2. A súlyos szívhibák is azonos eredménnyel operálhatók Down-szindrómás és nem Down-szindrómás gyermekeken. Bal-jobb sönttel járó vitiumok esetén minél korábbi életkorban szükséges a primer korrekció elvégzése. 3. Csecsemőkori korrekciós szívműtét után a Down-szindrómás betegek életkilátásai azonosak a nem szívbeteg társaikéval. Sorsukat „szociális helyzetük” határozza meg [1]. 1997-től napjainkig már minden Down-szindrómás szívbeteg korrekciós mútétre kerül úgy, mint a nem Down-szindrómás szívbeteg társaik.

A Szegedi Tudományegyetem, Szent-Györgyi Albert Klinikai Központ Szívsebészeti Osztályán 2013. január 1. és 2016. március 31. között 8 Down-szindrómás csecsemőn és 82, veleszületett szívhibás felnőtt betegen közülük 4 Down-szindrómáson - végeztünk korrekciós szívmütétet [2]. Utóbbiak közül 3 beteg fiatal felnőttkorú. Egy 24 éves betegnél az atrioventricularis septumdefektus primer korrekciója, egy 25 éves betegnél a csecsemőkorban korrigált atrioventricularis septumdefektus után a mitralis és tricuspidalis billentyú múbillentyưre történő cseréje, illetve egy 30 éves betegnél a panaszokat jelenleg okozó Fallot-IV primer rekonstrukciója történt meg. Vitát képezett egy 60 éves beteg mütéti indikációja, akinél a kritikus aortastenosis mútéti indikációja, szükségessége megvolt, de kérdéses volt, hogy a beteg hogy fogja viselni a mútéti megterhelést és a posztoperatív kezelést. Mind a négy beteg gyógyultan távozott, mútéti és korai mortalitás nem volt.

\section{Megbeszélés}

Az 1980-as és 1990-es években a diagnosztikában, a mútéti és a posztoperatív kezelésekben bekövetkezett forradalmi változások eredményeként napjainkra fokozatosan növekszik azoknak az operált szívbetegeknek a száma, akik megérik a felnőttkort [3-5]. Ez érinti a Down-szindrómás betegeket is. A szívsebész szemszögéből két jelentôs változás észlelhető napjainkban. 1. A praenatalis diagnosztika óriási fejlődésen ment keresztül, mind az echokardiográfia, mind a genetika területén. Ez oda vezetett, hogy a Down-szindrómás betegséget már a második, sőt az első terhességi trimeszterben is képesek korrekten diagnosztizálni. A korai praenatalis diagnózis felerősítette azt a tendenciát, hogy e kromoszómabetegség esetén megszakítsák a terhességet. Franciaországban a 30 évnél fiatalabb anyák 95\%-a dönt a Down-szindrómás terhesség megszakítása mellett [6], míg például az Amerikai Egyesült Államokban a beavatkozás 92\%-ról az utóbbi években 68-85\%-ra csökkent [7]. Utóbbihoz hasonlóak a hazai adatok is, ezért a szívmütétek végzésénél továbbra is számítani kell erre a betegcsoportra [2]. A felnőttkorú Down-szindrómás betegek sorsát vizsgálva érdekes megállapításra jutunk. Jelentősen meghosszabbodott az életkoruk; például az Amerikai Egyesült Államokban 1983tól 1997-ig átlagéletkoruk 25 évről 49 évre emelkedett [8], míg Európában Bittles és mtsai [9] szerint 40 év alatt 12 évről 60 évre. Majdalany és mtsai [10] szerint a betegek 14\%-a már megéri a 70 éves életkort. 
Napjainkban egyre nagyobb számban jelennek meg olyan közlemények, amelyek azzal foglalkoznak, hogy a Down-szindrómához társuló betegségek lefolyása hogyan változik az életkor előrehaladtával. Malt és mtsai [11] vizsgálatai a kora felnőttkorra terjednek ki. A respirációs és gastrointestinalis panaszok 30 éves kor előtt fokozódnak, növekszik a mitralis prolapsusos esetek száma. Az esetek felében a hypothyreosis és az obstruktív alvási apnoe, míg az esetek egyötödében a coeliakia válik vezető tünetté. A hallás csökkenése, a cataracta kialakulása, az atlantoaxialis gerincinstabilitás is jelentős lehet 30 éves kor előtt, és már ekkor elkezdődhet és fokozódhat a pszichomotoros retardáció és az Alzheimer-kór is. Esbensen [12] vizsgálatai szerint előtérbe kerülnek a bőr- és hajelváltozások, a korai menopauza lehetősége, az epilepsziakészség, a hypothyreosis, a diabetes, az obesitas, az alvási apnoe és a gerincterhelhetőségi problémák.

Roizen és Patterson [13] szerint 50 éves kor után ugrásszerúen emelkednek az Alzheimer-kór tünetei, 60 év felett ez már a betegek 75\%-át érinti, 58\%-ban jelentkezik gyakori epilepszia, 46\%-ban személyiségzavar, 46\%ban fokális neurológiai tünetek, 36\%-ban apathia alakul ki, és megnövekszik a leukaemia gyakorisága is. Közleményekben hosszasan taglalják, hogy az időskort megérő Down-szindrómás beteget hogyan viseli meg a szülők elvesztése („dad died”), mi a teendő hypothyresois, alvási apnoe, osteoarthritis, atlantoaxialis és nyaki gerincinstabilitás, osteoporosis, coeliakia, Alzheimer-kór előrehaladásakor [14]. Ezekből a problémákból is látszik az, hogy az időskorú Down-szindrómások speciális betegcsoportot képeznek (például a Down-szindrómás betegek átlagéletkora sokkal rövidebb az átlagpopulációénál stb.). Sajnos egy közlemény sem foglalkozik azonban azzal, hogy az ezeknél a betegeknél jelentkező sebészileg korrigálható cardialis problémák operálhatók-e, és ha igen, mikor? A betegek biológiai életkora, társuló betegségei, neurológiai-pszichológiai állapotuk alkalmas-e arra, hogy a jelentős megterhelést okozó szívsebészeti beavatkozást kellően türjék, a szívmütét javítja-e annyira az életminőségüket, meghosszabbítja-e az életüket úgy, hogy érdemes lenne a műtét elvégzése.

\section{Következtetések}

Az 1997. évi vizsgálatsorozatunk után mi, szívsebészek konszenzusra jutottunk a gyermekkardiológusokkal, a gyermekgyógyászokkal és a genetikusokkal abban, hogy sikeres szívmútétek után a veleszületett szívhibás Downszindrómás gyermekek életminősége, életkilátása hasonló lesz nem szívbeteg Down-szindrómás társaikéhoz. Ezért azóta minden ilyen beteget megoperálunk, megadva a lehetőséget a jobb életvitelhez. Jelenleg keressük a hasonló konszenzus felállításának a lehetőségét a felnőttkorú Down-szindrómás betegek esetén is. Adva van egy olyan szívsebészeti osztály, ahol nagy, egyre gyarapodó tapasztalattal, jó eredményekkel operáljuk a felnőttkorú veleszületett szívbetegeket, közte a Down-szindró- másokat is. E betegek sorsának eldöntéséhez szükség lenne a belgyógyász, a kardiológus kollégák és a Downszindrómás betegeket gondozók segítségére.

Anyagi támogatás: A közlemény elkészítése anyagi támogatásban nem részesült.

Szerzői munkamegosztás: H. I., B. G.: A hipotézisek kidolgozása, a vizsgálat lefolytatása és a kézirat megszövegezése. H. I.: Statisztikai elemzések. A cikk végleges változatát mindkét szerző elolvasta és jóváhagyta.

Érdekeltségek: A szerzőknek nincsenek érdekeltségeik.

\section{Irodalom}

[1] Hartyánszky, I., Dobos, M., Szabolcs, J., et al.: Life expectancy in Down's syndrome infants and children with congenital heart defects 1974-1997. [A Down-szindrómás szívbeteg csecsemók és gyermekek életkilátásai 1974-1997 között.] Orv. Hetil., 2000, 141(39), 2119-2122. [Hungarian]

[2] Hartyánszky, I., Varga, S., Csepregi, L., et al.: Surgical management of congenital heart defects beyond the age of 60 . [Veleszületett szívhibák sebészi kezelése 60 éves kor felett.] Orv. Hetil., 2016, 157(21), 820-824. [Hungarian]

[3] Hartyánszky, I., Székely, A., Király, L., et al.: Surgical management of congenital heart defects in adolescent and adult patients, between years 2001-2008. [Tapasztalataink a fiatal- és felnőttkori veleszületett szívhibák sebészi kezelésében 2001-2008.] Orv. Hetil., 2009, 150(37), 1739-1743. [Hungarian]

[4] Hartyánszky, I., Varga, S., Havasi, K., et al.: Perspectives in the management of congenital heart defects in adult patients. [Perspektívák a veleszületett szívhibák felnőttkori sebészi kezelésében.] Orv. Hetil., 2015, 156(3), 92-97. [Hungarian]

[5] Havasi, K., Kalapos, A., Berek, K., et al.: More than 50 year's experience in the treatment of patients with congenital heart disease in a Hungarian university hospital. The basics of the CSONGRAD Registry. [Több mint 50 év tapasztalat a congenitalis szívbetegek ellátásában egy magyar egyetemi központban. A CSONGRÁD Regiszter alapadatai.] Orv. Hetil., 2015, 156(20), 794-800.

[6] De Vigan, C., Khoshnood, B., Cadio, E., et al.: Prenatal diagnosis and prevalence of Down syndrome in the Parisian population, 2001-2005. Gynecol. Obstet. Fertil., 2008, 36(2), 146-150.

[7] Natoli, J. L., Ackerman, D. L., McDermott, S., et al.: Prenatal diagnosis of Down syndrome: a systematic review of termination rates (1995-2011). Prenat. Diagn., 2012, 32(2), 142-153.

[8] Yang, Q., Rasmussen, S. A., Friedman, J. M.: Mortality associated with Down's syndrome in the USA from 1983 to 1997: a population-based study. Lancet, 2002, 359(9311), 1019-1025.

[9] Bittles, A. H., Bower, C., Hussain, R., et al.: The four ages of Down syndrome. Eur. J. Public Health, 2006, 17(2), 221-225.

[10] Majdalany, D. S., Burkhart, H. M., Connolly, H. M., et al.: Adults with Down syndrome: safety and long-term outcome of cardiac operation. Congenit. Heart Dis., 2010, 5(1), 38-43.

[11] Malt, E. A., Dabl, R. C., Haugsand, T. M., et al.: Health and disease in adults with Down syndrome. Tidsskr. Nor. Laegeforen., 2013, 133(3), 290-294.

[12] Esbensen, A. J.: Health conditions associated with aging and end of life of adults with Down syndrome. Int. Rev. Res. Ment. Retard., 2010, 39(C), 107-126.

[13] Roizen, N. J., Patterson, D.: Down's syndrome. Lancet, 2003, 361(9365), 1281-1289.

[14] Moran, J.: Aging and Down syndrome. A health and well-being guidebook. National Down Syndrome Society, New York 2013.

(Hartyánszky István dr., Szeged, Pécsi u. 4., 6720 e-mail: hartyanszky@hotmail.com) 